\title{
The Potential Role of S-10oß Protein in Evaluation of CNS Affection and Prediction of Mortality in Acute Phosphides Intoxication
}

\author{
Marwa M. Shahin, Arwa A. Abuelfadl ${ }^{1}$ and Ahmed N.M. Zaki \\ ${ }^{1}$ Departments of Forensic Medicine and Clinical Toxicology, Faculty of Medicine, Tanta University, Tanta, Egypt \\ 2 Departments of Clinical Pathology, Faculty of Medicine, Tanta University, Tanta, Egypt
}

\begin{abstract}
Phosphides poisoning is a commonly encountered poisoning in most developing countries and is emerging as a common self-poisoning agent. Over the past 20 years, biochemical markers of brain damage have been increasingly studied as potential tools for prognostic evaluation. S-100 $\beta$ protein is the $\beta$-subunit of a calcium binding protein present mainly in glial and Schwann cells. The current study was conducted to evaluate central nervous system affection and the prognostic value of S-100 $\beta$ protein for prediction of mortality after acute phosphides intoxication. Twenty nine patients admitted to Poison Control Unit (Emergency Hospital, Tanta University) suffering from acute phosphide poisoning in nine months period were included in this study. For all patients sociodemographic, clinical and toxicological data were explored. One milliliter venous blood was withdrawn for analysis of S-100 $\beta$ protein level. Primary outcome included mortality. Meanwhile, secondary outcomes included GCS, hypotension and length of hospital stay. There was statistical significant difference between survivor patients and non-survivor patients regarding blood pressure. Meanwhile, no statistical significant difference was noticed between survivors and non-survivors in either GCS, pulse or duration of hospital stay. Toxicological data of the participant patients revealed that $(96.6 \%)$ of patients were in suicidal attempts by oral route. Zink phosphide was identified in (75.9\%) of patients, while, aluminum phosphide was recognized in (24.1\%) patients. Serum level of S-100 $\beta$ concentrations was significantly increased in phosphide intoxicated patients compared to the reference value for detection of injury to neural tissue $(0.1 \mu \mathrm{g} / \mathrm{L})$. There was significant negative statistical correlation between serum S-100 $\beta$ concentrations and GCS. Analysis of (ROC) curve of serum S-100 $\beta$ level as a predictor of mortality showed (AUC) $=0.956, \mathrm{P}<0.0001 *$ at a cut off value $>1.762 \mathrm{ug} / 1$, serum $\mathrm{S} 100 \beta$ had a sensitivity of $100 \%$ and a specificity $95 \%$. (PPV) was $95 \%$, while (NPV) was $100 \%$.
\end{abstract}

Keywords Phosphides, toxicity, CNS, S100 $\beta$, mortality, prediction.

\section{Introduction}

$\mathrm{M}$ etal phosphides are potent, extremely toxic and highly effective insecticides and rodenticides. They are commercially used for protection of crops during storage, as well as during transportation. For many years, metal phosphides have major merits of being highly potent against broad spectrum of insect species, inexpensive, not affecting seed viability and leave little residues on food grains. Yet, they elicit extreme human toxic effects without available suitable antidote. Phosphides poisoning is a commonly encountered poisoning in emergency departments in most developing countries (Proudfoot, 2009; Bumbrah et al., 2012; Nagy et al., 2015).

Phosphides are found as powders or pellets, usually in the form of zink or aluminum or calcium and magnesium phosphide. Owing to increased agricultural and nonagricultural use, easy availability in markets as well as low price, phosphide is emerging as a common self-poisoning agent, with increasing number of cases in the past four decades. On the other hand, exposure is uncommonly accidental and rarely homicidal (El-Naggar and El-Mahdy, 2011; Singh et al., 2014). 
Acute phosphides poisoning is due to either direct salt ingestion or indirect inhalation of phosphine gas generated during approved use. Several mechanisms have been described for phosphides toxicity. Cellular damage and cardio-respiratory failure are the most common mechanisms of mortality and morbidity after poisoning (Proudfoot, 2009; Moghaddam et al., 2015).

According to Bumbrah et al., (2012), cytotoxic phosphine gas generated due to acid hydrolysis of metal phosphides affects heart, lungs, kidneys and gastrointestinal tract. Metal phosphides toxicity causes nausea, restlessness, abdominal pain, palpitation, pulmonary edema, cyanosis, hypotension, shock and cardiac arrhythmias. Other rare effects include hepatitis, acute tubular necrosis, disseminated intravascular coagulation and respiratory alkalosis. Their detrimental effects have been described by several authors over a long period of time. However, central nervous system intoxication has been described once by Guale et al. (1994).

Over the past 20 years, biochemical markers of brain damage have been increasingly studied as potential tools for prognostic evaluation (Kovesdi et al., 2010). S$100 \beta$ protein is the $\beta$-subunit of a calcium binding protein present mainly in glial and Schwann cells (Zimmer et al., 1995). Its concentrations increase in human blood and cerebrospinal fluid after a wide range of diseases or conditions leading to brain damage (Yardan et al., 2009). Despite growing evidence suggesting a potential clinical role for S-100 $\beta$ as a biomarker, its measurements are not widely used in clinical practice and are not considered standard of care (Kovesdi et al., 2010). Therefore, the current study aimed to evaluate central nervous system affection by phosphides through estimation of serum S$100 \beta$ protein concentrations, and to investigate the prognostic value of serum S-100 $\beta$ protein as a mortality predictor after acute phosphides intoxication.

\section{Patients \& methods}

This prospective observational cross sectional study was carried out following approval of research ethical committee of Tanta Faculty of Medicine. Patients admitted to Poison Control Unit (Emergency Hospital, Tanta University) suffering from acute phosphide poisoning in nine month period from the $1^{\text {st }}$ of November 2014 to $31^{\text {st }}$ of August 2015 was included in this study. Written informed consent was obtained from each patient or his/her guardians (if the patient was unable to participate in the consent process). Confidentiality of the data will be maintained by making code numbers (available to investigators only) for each patient. All the data were analyzed anonymously.

\section{Eligibility criteria}

Male or female patients, more than 15 years old (to increase the sample size) with acute phosphide poisoning (deliberate or accidental) were included in the study. The diagnosis was made on the basis of typical clinical manifestations together with reliable identification of the compound based on container brought by patient attendants. Subsequent confirmation was performed through silver nitrate test for phosphine detection in gastric contents.

Patients less than 15 years, patients exposed to other substances in addition to phosphide, patients with medical conditions (e.g. cardiovascular disease, renal or hepatic failure) were excluded. Similarly, patients presenting more than 12 hours of having phosphide compound (late presenters) and patients treated for acute phosphide poisoning in any medical center before admission were excluded.

\section{Interventions}

For all patients sociodemographic data (age, occupation, education, residence and marital state) and poisoning data (route \& circumstances of poisoning and prehospitalization period) were explored.

Clinical examination included vital signs (pulse, blood pressure, temperature and respiratory rate), neurological examination and level of consciousness (Glasgow Coma Scale, GCS) were done for every patient. Moreover, respiratory system, cardiovascular system, GIT and urinary system were evaluated for each of the participants. Blood pressure was continuously monitored and the lowest reading was recorded. Glasgow Coma Scale was assessed every four hours and with any change in conscious level, the lowest reading was recorded.

Blood samples were collected immediately after admission before administration of any medication under complete aseptic conditions. One milliliter venous blood was kept into a clean dry centrifuge tube and left to stand for few hours before centrifugation to avoid hemolysis. After sampling, the blood was centrifuged for $15 \mathrm{~min}$ at $1500 \mathrm{~g}$, and the serum was separated. It was stored and deep frozen at $-80^{\circ} \mathrm{C}$ until analysis of $\mathrm{S}-100 \beta$ protein level. The serum S- $100 \beta$ protein levels were measured by enzyme-linked immunosorbent assay with commercially available kits (BioVendor Laboratory Medicine, Inc., Modrice, Czech Republic) in a TECAN Sunrise absorbance reader.

\section{Outcome measures}

Primary outcome included mortality. Meanwhile, secondary outcomes included GCS, hypotension and length of hospital stay.

\section{Methods of Statistical analysis}

All statistical calculations were made using the Statistical Package for the Social Sciences for Windows version 21.0 software program. Data were analyzed with the Kolmogorov-Smirnov test for normality. Values were reported as median (minimum-maximum) for data that were not distributed normally. A value of $p<0.05$ was accepted as statistically significant.

To compare the groups, Mann-Whitney U test were used. Analysis of variables within categories was done with the Chi-square, Fisher's exact tests and Monte Carlo correction. Correlation analysis was performed with the Kendall's tau-b ( $\square$ ) test. Receiver-operating 
characteristic curves for predicting mortality were generated from the data. Sensitivity and specificity were also calculated for S100B levels using Medcalc software.

\section{Results}

A total of 29 patients poisoned by phosphides have participated in the study. Their median age was 20 years; range 15-50 years; of them 19 females, 10 males. Sociodemographic characteristics of the participant patients were illustrated in table (1). There was no statistical significant difference between survivor patients and non-survivor patients considering age, gender and residence.

Table (2) indicated clinical data of the participant patients, GCS ranged between 6.0-15.0 (13.621 \pm 2.36$)$ with a median of 14.000 . Mean arterial blood pressure fluctuated between 33.33-110.00 (82.87 \pm 20.15$)$, its median value was 90.00 . There was statistical significant difference between survivor patients and non-survivor patients regarding systolic blood pressure, diastolic blood pressure and mean arterial blood pressure. Meanwhile, no statistical significant difference was noticed between survivor patients and non-survivor patients in either GCS or pulse rate or duration of hospital stay; $p=0.077,0.095$ and 0.167 respectively.

Toxicological data of the participant patients are demonstrated in table (3). It revealed that, 28 (96.6\%) of patients were in suicidal attempts, while, only one patient (3.4\%) was accidental exposure. Similarly, oral route was registered in $28(96.6 \%)$ of cases and inhalation route represented one $(3.4 \%)$ of cases. Zink phosphide was identified in $22(75.9 \%)$ of patients, while, aluminum phosphide was recognized in 7 (24.1\%) patients. Pre hospital period ranged between $0.5-12$ hours with a mean value of $3.293 \pm 2.78$ and a median 2.000 hours. Statistical significant difference could be detected between survivor patients and non-survivor patients in both phosphide type and pre hospital period.

Serum level of S-100 $\beta$ concentrations recorded values between $0.710-2.656 \mu \mathrm{g} / \mathrm{L}(1.452 \pm 0.548)$ with a median 1.242 . It was significantly increased in phosphide intoxicated patients compared to the reference value for detection of injury to neural tissue $(0.1 \mu \mathrm{g} / \mathrm{L}) ; p<0.05$. Moreover, it registered statistical significant difference between survivor patients and non-survivor patients; $p=0.000$ as shown in table (3).

Table (4) revealed negative statistical correlation between serum $\mathrm{S} 100 \beta$ concentrations and GCS, systolic blood pressure, diastolic blood pressure, mean arterial blood pressure and positive statistical correlation with the length of hospital stay. However, such correlation was significant only with GCS ( $\mathrm{p}=0.003)$.

Analysis of receiver operating characteristics (ROC) curve of serum S-100 $\beta$ level as a predictor of mortality (Figure 1) showed an area under the curve $($ AUC $)=0.956$, with a $95.6 \%$ confidence interval $(80.7 \%$ - 99.8\%), P <0.0001*. At a cut off value $>1.762 \mathrm{ug} / \mathrm{l}$, serum S100 $\beta$ had a sensitivity of $100 \%$ (were able to predict all cases that died) and a specificity $95 \%$ (Table 5). Moreover, positive predictive value (PPV) has been calculated and was 95\%, while negative predictive value (NPV) was $100 \%$.

Table (1): Mann Whitney test and Pearson's Chi-squared test for comparison of sociodemographic data of survivors $(n=20)$ and non-survivors $(n=9)$ :

\begin{tabular}{|c|c|c|c|c|c|c|}
\hline & \multirow{2}{*}{$\begin{array}{l}\text { All patients } \\
\quad(n=29)\end{array}$} & \multirow{2}{*}{$\begin{array}{c}\text { Survivors } \\
(\mathbf{n}=20)\end{array}$} & \multirow{2}{*}{$\begin{array}{c}\text { Non-survivors } \\
(\mathbf{n}=\mathbf{9})\end{array}$} & \multicolumn{2}{|c|}{ Test of significance } \\
\hline & & & & & $\begin{array}{c}\text { Test } \\
\text { statistic }\end{array}$ & P value \\
\hline \multicolumn{2}{|c|}{$\begin{array}{l}\text { Age (years) } \\
\text { Minimum-maximum } \\
\text { Mean } \pm \text { S.D. } \\
\text { Median }\end{array}$} & $\begin{array}{l}15.0-50.0 \\
23.41 \pm 8.27 \\
20.00\end{array}$ & $\begin{array}{l}15.0-38.0 \\
23.55 \pm 7.007 \\
22.00\end{array}$ & $\begin{array}{l}15.0-50.0 \\
23.11 \pm 11.07 \\
19.00\end{array}$ & $\mathrm{Z}_{\mathrm{MW}}=0.733$ & $p=0.472 \mathrm{NS}$ \\
\hline \multirow[t]{2}{*}{ Gender } & Male & $10(23.5 \%)$ & $9(45.0 \%)$ & $1(11.1 \%)$ & \multirow[t]{2}{*}{$\mathrm{X}^{2}=3.155$} & \multirow{2}{*}{$\begin{array}{l}p_{\mathrm{FE}}=0.107 \\
\mathrm{NS}\end{array}$} \\
\hline & Female & $19(65.5 \%)$ & $11(55.0 \%)$ & $8(88.9 \%)$ & & \\
\hline \multirow[t]{2}{*}{ Residence } & Rural & $16(55.2 \%)$ & $12(60.0 \%)$ & $4(44.4 \%)$ & \multirow[t]{2}{*}{$X^{2}=0.607$} & \multirow{2}{*}{$\begin{array}{l}p_{\mathrm{FE}}=0.688 \\
\mathrm{NS}\end{array}$} \\
\hline & Urban & $13(44.8 \%)$ & $8(40.0 \%)$ & $5(55.6 \%)$ & & \\
\hline
\end{tabular}

$X^{2}$ : Pearson's Chi-squared test, $Z_{M W}: Z$ test of Mann Whitney, $P_{F E:}$ Fisher's Exact test, $P_{M C:}$ Monte Carlo corrected $P$ value NS: Not significant 
Table (2): Mann Whitney test for comparison of clinical data of survivors $(n=20)$ and non-survivors (n=9):

\begin{tabular}{|c|c|c|c|c|c|}
\hline & \multirow{2}{*}{ All patients $(n=29)$} & \multirow{2}{*}{ Survivors $\quad(n=20)$} & \multirow{2}{*}{ Non-survivors $(n=9)$} & \multicolumn{2}{|c|}{ Test of significance } \\
\hline & & & & Test statistic & $P$ value \\
\hline $\begin{array}{l}\text { GCS } \\
\text { Minimum-maximum } \\
\text { Mean } \pm \text { S.D. } \\
\text { Median }\end{array}$ & $\begin{array}{c}6.0-15.0 \\
13.621 \pm 2.36 \\
14.000\end{array}$ & $\begin{array}{c}14.0-15.0 \\
14.45 \pm 0.510 \\
14.000\end{array}$ & $\begin{array}{c}6.0-15.0 \\
11.778 \pm 3.66 \\
13.000\end{array}$ & $\mathrm{Z}_{\mathrm{MW}}=1.933$ & $p=0.077 \mathrm{NS}$ \\
\hline $\begin{array}{l}\text { SBP (mmHg) } \\
\text { Minimum-maximum } \\
\text { Mean } \pm \text { S.D. } \\
\text { Median }\end{array}$ & $\begin{array}{c}40.0-160.0 \\
113.10 \pm 29.28 \\
120.000\end{array}$ & $\begin{array}{c}100.0-160.0 \\
126.00 \pm 15.694 \\
130.00\end{array}$ & $\begin{array}{c}40.0-150.0 \\
84.44 \pm 32.82 \\
80.00\end{array}$ & $\mathrm{Z}_{\mathrm{MW}}=3.184$ & $p=0.001^{*}$ \\
\hline $\begin{array}{l}\text { DBP (mmHg) } \\
\text { Minimum-maximum } \\
\text { Mean } \pm \text { S.D. } \\
\text { Median }\end{array}$ & $\begin{array}{c}30.0-* 90.0 \\
57.75 \pm 16.77 \\
70.00\end{array}$ & $\begin{array}{c}50.0-90.0 \\
76.00 \pm 8.207 \\
75.00\end{array}$ & $\begin{array}{c}30.0-80.0 \\
49.44 \pm 16.66 \\
50.00\end{array}$ & $\mathrm{Z}_{\mathrm{MW}}=3.459$ & $p=0.000^{*}$ \\
\hline $\begin{array}{l}\text { MABP (mmHg) } \\
\text { Minimum-maximum } \\
\text { Mean } \pm \text { S.D. } \\
\text { Median }\end{array}$ & $\begin{array}{c}33.33-110.00 \\
82.87 \pm 20.15 \\
90.00 \\
\end{array}$ & $\begin{array}{c}80.0-110.0 \\
92.66 \pm 8.957 \\
90.00 \\
\end{array}$ & $\begin{array}{c}33.33-103.33 \\
61.11 \pm 21.40 \\
60.00 \\
\end{array}$ & $\mathrm{Z}_{\mathrm{MW}}=3.342$ & $p=0.000^{*}$ \\
\hline $\begin{array}{l}\text { Pulse (beats/min) } \\
\text { Minimum-maximum } \\
\text { Mean } \pm \text { S.D. } \\
\text { Median }\end{array}$ & $\begin{array}{c}65.0-152.0 \\
101.31 \pm 22.93 \\
92.00\end{array}$ & $\begin{array}{c}70.0-120.0 \\
94.60 \pm 14.492 \\
90.00\end{array}$ & $\begin{array}{c}65.0-152.0 \\
116.22 \pm 31.3 \\
127.00\end{array}$ & $\mathrm{Z}_{\mathrm{MW}}=1.705$ & $p=0.095 \mathrm{NS}$ \\
\hline
\end{tabular}

GCS: Glasgow Coma Scale, SBP: Systolic Blood Pressure, DBP: Diastolic Blood Pressure, MABP: Mean Arterial Blood Pressure, S.D.: Standard Deviation, $Z_{M W}$ : $Z$ test of Mann Whitney, * significant at $p<0.05$, NS: Not significant

Table (3): Mann Whitney test and Pearson's Chi-squared test for comparison of toxicological data of survivors $(\mathbf{n}=\mathbf{2 0})$ and non-survivors $(\mathbf{n}=\mathbf{9})$ :

\begin{tabular}{|c|c|c|c|c|c|c|}
\hline & \multirow{2}{*}{$\begin{array}{l}\text { All patients } \\
\qquad(n=29)\end{array}$} & \multirow{2}{*}{$\begin{array}{l}\text { Survivors } \\
(n=20)\end{array}$} & \multirow{2}{*}{$\begin{array}{c}\text { Non-survivors } \\
(n=9)\end{array}$} & \multicolumn{2}{|c|}{ Test of significance } \\
\hline & & & & & $\begin{array}{c}\text { Test } \\
\text { statistic }\end{array}$ & $P$ value \\
\hline \multirow{2}{*}{$\begin{array}{l}\text { Manner of } \\
\text { poisoning }\end{array}$} & Suicidal & $28(96.6 \%)$ & $20(100.0 \%)$ & $8(88.9 \%)$ & \multirow[t]{2}{*}{$X^{2}=2.302$} & \multirow{2}{*}{$\begin{array}{l}p_{\mathrm{FE}}=0.310 \\
\text { NS }\end{array}$} \\
\hline & Accidental & $1(3.4 \%)$ & $0(0.0 \%)$ & $1(11.1 \%)$ & & \\
\hline \multirow[t]{2}{*}{ Route } & Oral & $28(96.6 \%)$ & $20(100.0 \%)$ & $8(88.9 \%)$ & \multirow[t]{2}{*}{$X^{2}=2.302$} & \multirow{2}{*}{$\begin{array}{l}p_{\mathrm{FE}}=0.310 \\
\mathrm{NS}\end{array}$} \\
\hline & Inhalation & $1(3.4 \%)$ & $0(0.0 \%)$ & $1(11.1 \%)$ & & \\
\hline \multirow[t]{2}{*}{ Type } & Zinc Phosphide & $22(75.9 \%)$ & $20(100.0 \%)$ & $2(22.2 \%)$ & \multirow[t]{2}{*}{$X^{2}=20.505$} & \multirow[t]{2}{*}{$p_{\mathrm{FE}}=0.000^{*}$} \\
\hline & $\begin{array}{l}\text { Aluminum } \\
\text { Phosphide }\end{array}$ & 7 (24.1\%) & $0(0.0 \%)$ & $7(77.8 \%)$ & & \\
\hline \multicolumn{2}{|c|}{$\begin{array}{l}\text { Pre hospital period (hrs) } \\
\text { Minimum-maximum } \\
\text { Mean } \pm \text { S.D. } \\
\text { Median }\end{array}$} & $\begin{array}{c}0.5-12.0 \\
3.293 \pm 2.78 \\
2.000\end{array}$ & $\begin{array}{c}0.5-10.0 \\
2.800 \pm 2.567 \\
2.000\end{array}$ & $\begin{array}{c}1.5-12.0 \\
4.389 \pm 3.100 \\
3.000\end{array}$ & $\mathrm{Z}_{\mathrm{MW}}=2.094$ & $p=0.039^{*}$ \\
\hline \multicolumn{2}{|c|}{$\begin{array}{l}\text { Hospital stay (hours) } \\
\text { Minimum-maximum } \\
\text { Mean } \pm \text { S.D. } \\
\text { Median }\end{array}$} & $\begin{array}{c}1.0-13.5 \\
2.96 \pm 2.57 \\
2.00\end{array}$ & $\begin{array}{c}1.0-3.0 \\
2.10 \pm 0.660 \\
2.00\end{array}$ & $\begin{array}{c}1.0-13.5 \\
4.87 \pm 4.024 \\
5.00\end{array}$ & $\mathrm{Z}_{\mathrm{MW}}=1.434$ & $p=0.167 \mathrm{NS}$ \\
\hline \multicolumn{2}{|c|}{$\begin{array}{l}\text { S100b } \\
\text { Minimum-maximum } \\
\text { Mean } \pm \text { S.D. } \\
\text { Median }\end{array}$} & $\begin{array}{c}0.710-2.656 \\
1.452 \pm 0.548 \\
1.242\end{array}$ & $\begin{array}{c}0.710-2.507 \\
1.174 \pm 0.395 \\
1.091\end{array}$ & $\begin{array}{c}1.829-2.656 \\
2.071 \pm 0.237 \\
2.033\end{array}$ & $\mathrm{Z}_{\mathrm{MW}}=3.866$ & $p=0.000^{*}$ \\
\hline
\end{tabular}

* significant at $p<0.05, X^{2}:$ Pearson's Chi-squared test, $P_{F E}$ Fisher's Exact test, $Z_{M W}$ : $Z$ test of Mann Whitney, S.D.: Standard Deviation, NS: Not significant. 
Table (4): Kendall's tau-b test for correlation of $S 100 \beta$ serum level with some clinical variables in patients with phosphide poisoning:

\begin{tabular}{|c|c|c|}
\hline & \multicolumn{2}{|c|}{$\mathrm{S} 100 \beta$} \\
\hline & $\tau$ & $\mathbf{p}$ \\
\hline GCS & -0.316 & $0.033^{*}$ \\
\hline Systolic Bl.Pr. & -0.240 & 0.078 NS \\
\hline Diastolic Bl.Pr. & -0.160 & $0.259 \mathrm{NS}$ \\
\hline Mean Arterial Bl.Pr & -0.160 & $0.234 \mathrm{NS}$ \\
\hline Hospital stay & 0.245 & $0.076 \mathrm{NS}$ \\
\hline
\end{tabular}

* significant at $p<0.05$, NS: Not significant

Table (5): Best cutoff, sensitivity, specificity, and area under the curve (AUC) values of serum S100 $\beta$ for predicting the mortality (95\% confidence interval (CI)).

\begin{tabular}{|l|l|}
\hline & \multicolumn{1}{|c|}{ S100 $\boldsymbol{\beta}$} \\
\hline Best cutoff & 1.762 \\
\hline Sensitivity & $100.0 \%$ \\
\hline Specificity & $95.0 \%$ \\
\hline AUC & $0.956(0.807$ to 0.998$)$ \\
\hline Z statistics & 10.171 \\
$p$ value & $<0.0001^{*}$ \\
\hline +ve Predictive value (PPV) & $90.0 \%$ \\
\hline -ve Predictive value (NPP) & $100.0 \%$ \\
\hline
\end{tabular}

* significant at $\mathrm{p}<0.05$

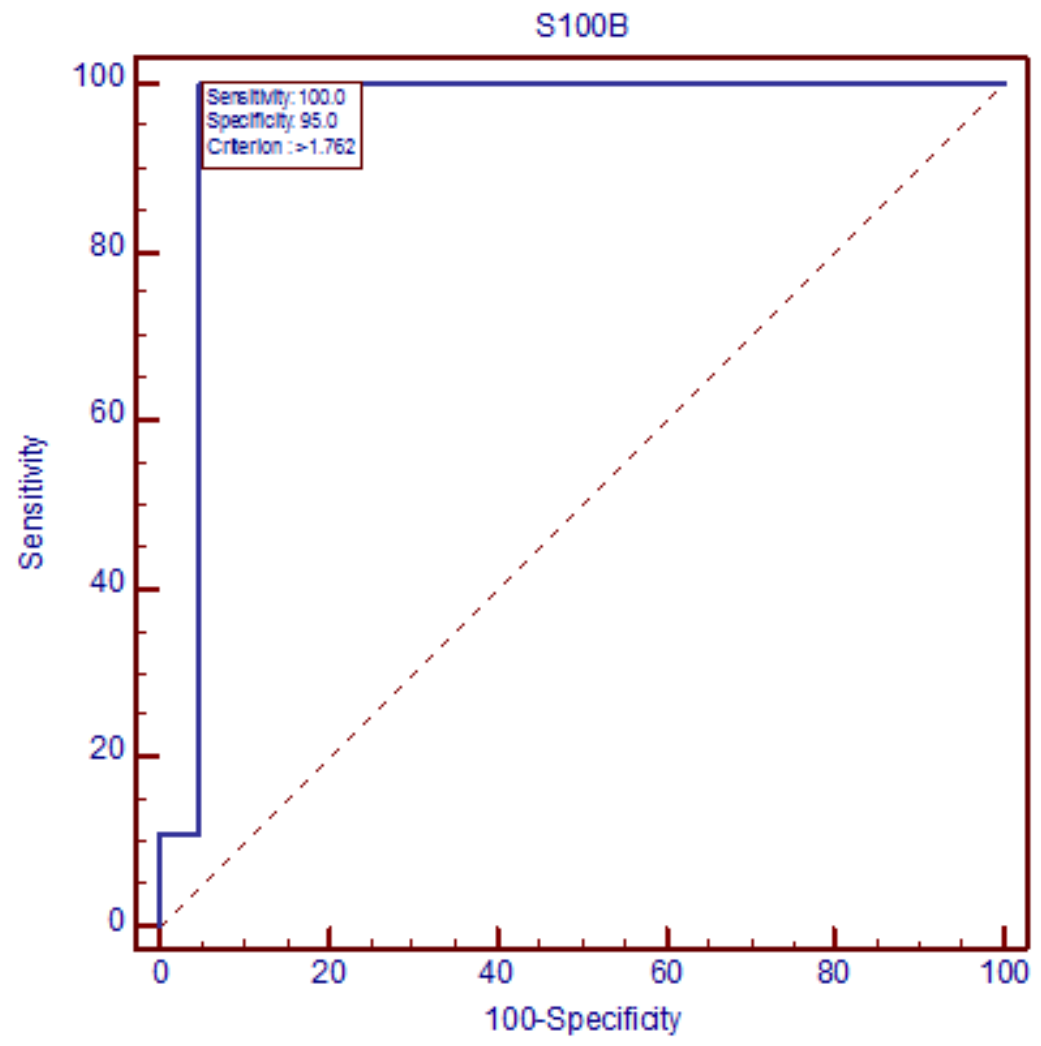

Figure (1): ROC curve analysis (S100ß as predictor of mortality). Area under the curve $=0.956, P<0.0001 *$, sensitivity $100 \%$ \& specificity $95.0 \%$ at cut off value $>1.762 \mathrm{ug} / \mathrm{l}$. 


\section{Discussion}

Metal phosphides, including aluminum and zinc phosphide, are used throughout the world as pesticides to protect stored grains from rodents and other pests. It liberates toxic phosphine gas following contact with water, moisture in the air, or hydrochloric acid in the stomach (Shadnia et al., 2005). Phosphides (aluminum and zinc) poisoning are commonly used to commit suicide in Egypt and developing countries due to its low price and easy availability (Lall et al., 1997, Hsu et al., 2002 ; El Naggar \& El Mahdy, 2011).

The current study aimed to evaluate central nervous system affection by phosphides through estimation of serum S-100 $\beta$ protein concentrations, and to investigate the prognostic value of serum S-100 $\beta$ protein as a mortality predictor after acute phosphides intoxication.

The results of the present study showed that the mean age, gender, residence, route and mode of poisoning were more or less in agreement with findings in majority of centers in Egypt and across the world (Schmidtke et al., 1996; Hawton et al., 1999; Hulten et al., 2000; Kapoor et al., 2006; Mehrpour et al., 2008; El Naggar \& El Mahdy, 2011; Hosseinian et al., 2011; Khurana et al., 2011; Vijayanath et al., 2011; Soltaninejad et al., 2012).

Zinc phosphide represented $75.9 \%$ of cases in the current study, while aluminum phosphide represented $24.1 \%$ of cases. However, there was a significant statistical difference between survivors and non survivors in both aluminum and zinc phosphide intoxicated patients. Where, all aluminum phosphide cases have died and only two cases of zink phosphide have died.

Such high death rate in aluminum phosphide could be explained in light of rapid release of highly toxic phosphine gas by action of dilute hydrochloric acid content of the stomach. It blocks cytochrome $\mathrm{C}$ oxidase enzyme, hence, mitochondrial oxidative phosphorylation is inhibited. In addition, it disturbs mitochondrial morphology, inhibits oxidative respiration by $70 \%$ and causes severe drop in mitochondrial membrane potential, causing, in turn, the cells to die rapidly (Bumbrah et al., 2012).

On the other hand, zinc phosphide is slower in onset since it releases phosphine gas more slowly than aluminum phosphide (Goel \& Aggarwal, 2007). Ingestion of as little as half a tablet of aluminum phosphide will probably lead to death (aluminum phosphide lethal dose is $0.15-0.5 \mathrm{~g}$ ), while, zinc phosphide maximum tolerated dose is $50 \mathrm{~g}$ (Stephenson, 1967; Goel \& Aggarwal, 2007; Wahab et al., 2008).

In the present study, pre-hospitalization period ranged from 0.5-12 hours. There was a significant statistical difference between survivors and non survivors regarding pre-hospitalization period. This is consistent with findings of Mehrpour et al. (2008) who observed that the duration between exposure and arrival to hospital was $2.8 \pm 0.3$ hours in survival while cases that died had a longer duration of $4.2 \pm 0.7$ hours. This could be attributed to rapid generation of phosphine gas which is rapidly absorbed throughout the gastrointestinal tract, reaches the blood stream. Therefore, delay in seeking medical advice might increase morbidity and mortality (Wexler, 2005).

Louriz et al. (2009) found that Glasgow coma scale (GCS) of patients poisoned by phosphides ranged between 8 and 15 which coincide with the results of this study. Where, GCS ranged between 6-15 with no statistical significant difference between survivors and non-survivors. Glasgow coma scale might be an indicant of CNS affection by phosphide intoxication according to Guale et al. (1994). They described central nervous system intoxication and depression as clinical signs in phosphides poisoning.

The results of the current study recorded median values for systolic, diastolic and mean arterial blood pressure of 120, 70 and $90 \mathrm{mmHg}$ respectively. In addition to statistical significant differences between survivors and non-survivor patients considering systolic, diastolic and mean arterial blood pressure. These findings could be explained in light of data gathered by Chugh et al. (1998) who reported non-recordable blood pressure and shock as the most common manifestations following phosphides ingestion. Furthermore, Rodenberg et al. (1989) advocated that after phosphides ingestion delayed death results from cardiotoxicity due to the absorption of trace amount of phosphide into body.

$\mathrm{S}-100 \beta$ is a calcium-binding protein produced and released by astrocytes. It has neurotropic and gliotropic activity, that is important for CNS recovery after various types of injury (Yardan et al., 2009). Likewise, S-100 $\beta$ is involved in CNS energy metabolism regulation and many immunological functions (Rothermundt et al., 2003). Increased S-100 $\beta$ levels are associated with variety of poisonings affecting CNS, such as carbon monoxide poisoning and benzodiazepine overdose (Ambrozic et al., 2008; Yardan et al., 2009; Cakir et al., 2010). Based on these reports, significantly elevated serum levels of S-100 $\beta$ in phosphides intoxicated patients, compared to the reference value, is an indication for phosphides induced neural tissue injury.

Such phosphides induced neural injury was previously mentioned once by Guale et al. (1994). They described central nervous system intoxication as clinical sign in phosphides poisoning. In post-mortem reports; Tripathi and Pandey (2007) reported distinct changes in the cerebral and cerebellar cortex due to the effect of phosphides on human brain. Additionally, Mehrpour et al. (2008) observed mild capillary dilation and congestion of cortex, cerebral edema, and cerebellar edema. They also observed degenerated Nissel granule in the cytoplasm and deeply stained degenerated eccentric nucleus in brain cortex and degenerated neuron and 
infiltration of round cell into the molecular layer in cerebella.

To the best of the authors' knowledge, the current study is the first to investigate the serum levels of S-100 $\beta$ in phosphides poisoned patients. Serum S-100 $\beta$ levels in non-survivors group were significantly higher than in survivors group. These results support that, increased S100B levels are associated with severe phosphides induced neural damage. Besides, such results might spot light on CNS toxicity as a cause of death in phosphides intoxication. A proposal that contrast the usually proposed cause of death in phosphides toxicity which is respiratory and cardiac arrest (Mathiharan and Patnaik, 2008).

There was a negative correlation between serum S-100 $\beta$ concentrations and GCS, systolic blood pressure, diastolic blood pressure, mean arterial blood pressure and a positive correlation with length of hospital stay. It means that, the lower GCS, systolic blood pressure, diastolic blood pressure, mean arterial blood pressure, the higher S-100 $\beta$ concentrations are and the longer hospital stay, the higher S-100 $\beta$ concentrations are. However, such correlation was significant only with GCS that could be attributed to the small sample size.

Phosphide induced mortality is very high. Thus, predicting its outcome is one of the vital issues. Acute Physiology and Chronic Health Evaluation II (APACHE II) and Simplified Acute Physiology Score II (SAPS II), two of several intensive care units scoring systems, have demonstrated an ability to predict mortality rates in phosphides poisoning (Bumbrah et al., 2012).

Hajouji Idrissi et al. (2006) found that APACHE II and SAPS II were positively correlated with poor outcome in phosphides poisoning. Louriz et al. (2009) evaluated the predictive power of APACHE II in aluminum phosphide poisoning. Shadnia et al. (2010) concluded that SAPS II calculated within the first $24 \mathrm{~h}$ was a good prognostic indicator. Studies have been conducted on the role of a single clinical and/or paraclinical finding in predicting the outcome of acute aluminium phosphide poisoning (Chugh et al., 2000; Shadnia et al., 2009; Mathai et al., 2010).

Providentially, high S-100 $\beta$ levels might be a predictor for mortality in acute phosphides intoxication. In the present study, it was determined that an S-100 $\beta$ value over the cutoff value $>1.762 \mathrm{ug} / \mathrm{l}$ was sensitive and specific in the prediction of mortality, with sensitivity of $100 \%$ and a specificity $95 \%$. Moreover, PPV was $95 \%$ and NPV was $100 \%$; which means that, above the level of $1.762 \mathrm{ug} / \mathrm{l}, \mathrm{S}-100 \beta$ could predict death in $95 \%$ of patients, and below this level, death could excluded as an outcome in $100 \%$ of patients. These data suggest that S100B may be helpful in predicting mortality of phosphides intoxicated patients. However, it will require further researches to investigate and evaluated the predictive power of serum S-100 $\beta$ values as mortality predictor.

\section{Study limitations}

Small sample size comprises a major study limitation in this study as larger sample size might reflect statistically significant correlations rather than statistical correlations between serum S-100 $\beta$ and systolic blood pressure, diastolic blood pressure, mean arterial blood pressure and length of hospital stay.

Identification of phosphide type is usually made from the history where, aluminum phosphide is formulated in solid form as tablets or pellets placed in porous bags or blister packs, on the other hand, zinc phosphide is a steel gray crystalline powder.

There was no standard sampling time for S$100 \beta$ after poisoning event. Nevertheless, it is impossible to control the time interval between poisoning and S$100 \beta$ sampling because it depends on time between poisoning and patient arrival to ED.

S- $100 \beta$ was measured once on admission. A series of measurements over time may provide more insight into the role of this marker in acute phosphide poisoning.

Conclusion:

From the result of the present study, it could be concluded that:

- Phosphide induced CNS damage is an issue that require further investigations to be confirmed using different tools.

- $\quad$ S- $100 \beta$ protein as predictor for mortality in phosphide intoxicated patients require further evaluation.

\section{References}

Ambrozic J, Bunc M, Osredkar J, et al., (2008): "S100B protein in benzodiazepine overdose". Emerg Med J, 25: 90-92.

Bumbrah GS, Krishan K, Kanchan T, et al., (2012): "Phosphide poisoning: a review of literature". Forensic science international, 214: 1-6.

Cakir Z, Aslan S, Umudum Z, et al., (2010): "S-100beta and neuron-specific enolase levels in carbon monoxide-related brain injury". Am J Emerg Med, 28: 61-67.

Chugh SN, Aggarwal HK, Mahajan SK, (1998): "Zinc phosphide intoxication symptoms: analysis of 20 cases". Int. J. Clin. Pharmacol. Ther., 36: 406407.

Chugh SN, Kishore K, Aggarwal N, et al., (2000): "Hypoglycaemia in acute aluminium phosphide poisoning". J. Assoc. Physicians India, 48: 855856.

El Nagar AM and El Mahdy NM (2011): "Zinc phosphide toxicity with a trial of tranexamic acid in its management". Journal of Advanced Research, 2:149-156.

Goel A and Aggarwal P (2007): "Pesticide poisoning". The National Medical Journal of India, 20:182191. 
Guale FG, Stair EL, Johnson BW, et al., (1994): "Laboratory diagnosis of zinc phosphide poisoning". Vet. Hum. Toxicol., 36:517-519.

Hajouji Idrissi M, Oualili L, Abidi K, et al., (2006): "Severity factors of aluminium phosphide poisoning (phostoxin)". Ann. Fr. Anesth. Reanim, 25: 382-385.

Hawton K, Houston K, Shepperd R., (1999): "Suicide in young people. Study of 174 cases, aged under 25 years, based on coroners' and medical records". Br J Psychiatry, 175:271-6.

Hosseinian A, Pakravan N, Rafiei A, et al., (2011): "Aluminum phosphide poisoning known as rice tablet: a common toxicity in North Iran". Indian journal of medical disease, 65 (4): 143-150.

Hsu CH, Chi BC, Liu MY, et al., (2002): "Phosphineinduced oxidative damage in rats: role of glutathione". Toxicology, 179 (1-2):1-8.

Hulten A, Wasserman D, Hawton K, et al. (2000): "Recommended care for young people (15-19 years) after suicide attempts in certain European countries". Eur Child Adolesc Psychiatry, 9 (2):100-8.

Kapoor AK, Sinha US, Singh AK, et al., (2006): “An Epidemiological study of aluminium phosphide poisoning at Allahabad". Indian Internet Journal of Forensic Medicine and Toxicology, 4 (1): 1970-1973.

Kovesdi E, Luckl J, Bukovics P, et al., (2010): "Update on protein biomarkers in traumatic brain injury with emphasis on clinical use in adults and pediatrics". Acta Neuro chir, 152: 1-17.

Lall SB, Sinha K, Mittra S, et al., (1997): “An experimental study on cardiotoxicity of aluminium phosphine". Indian Journal of Experimental Biology, 35: 1060-1064.

Louriz M, Dendane T, Abidi K, et al., (2009): "Prognostic factors of acute aluminum phosphide poisoning". Indian Journal of Medical Sciences, 63 (6): 227-234.

Mathai A and Bhanu MS, (2010): "Acute aluminium phosphide poisoning: can we predict mortality?". Indian J. Anaesth., 54: 302-307.

Mathiharan K and Patnaik AK (2008): Modi's Medical Jurisprudence and Toxicology, Rakmo Press, New Delhi.

Mehrpour O, Alfred S, Shadnia S, et al, (2008): "Hyperglycemia in acute aluminum phosphide poisoning as a potential prognostic factor". Human \& Experimental Toxicology, 27: 591595.

Mehrpour O, Mandana D, Soltaninejad K, et al., (2008): "Evaluation of histopathological changes in fatal aluminium phosphide poisoning”. Indian J. For. Med. Toxicol., 2: 7-12.

Moghaddam HH, Zamani N, Rahimi M, et al., (2015): "Successful Treatment of Aluminium Phosphide Poisoning by
Extracorporeal Membrane Oxygenation (ECMO)". Basic and clinical pharmacology and toxicology. Sep 3. doi: 10.1111/bcpt.12481. [Epub ahead of print]

Nagy AL, Bolfa P, Mihaiu M, et al., (2015): "Intentional fatal metallic phosphide poisoning in a dog--a case report". BMC veterinary research journal, 11: 158.

Proudfoot AT (2009): "Aluminium and zinc phosphide poisoning”. Clinical Toxicology (Philadelphia) journal, 47 (2): 89-100.

Rodenberg HD, Chang CC, Watson WA, (1989): “Zinc phosphide ingestion: a case report and review". Vet. Hum. Toxicol. 31: 559-562.

Rothermundt M, Peters M, Prehn JH, et al., (2003): "S100B in brain damage and neurodegeneration”. Microsc Res Technol, 60: 614-632.

Schmidtke A, Bille Brahe U, DeLeo D, et al. (1996): "Attempted suicide in Europe: rates, trends and sociodemographic characteristics of suicide attempters during the period 1989-1992. Results of the WHO/EURO Multicentre Study on Parasuicide". Acta Psychiatr Scand, 93 (5):32738.

Shadnia G, Sasanian P, Allami A, et al., (2009): “A retrospective 7-years study of aluminum phosphide poisoning in Tehran: opportunities for prevention". Hum. Exp. Toxicol, 28: 209213.

Shadnia S, Mehrpour O, Soltaninejad K, (2010): "A simplified acute physiology score in the prediction of acute aluminium phosphide poisoning outcome". Indian J. Med. Sci., 64: 532-539. S.

Shadnia S, Rahimi M, Pajoumand A, et al., (2005): "Successful treatment of acute aluminium phosphide poisoning: possible benefit of coconut oil". Human and Experimental Toxicology, 24:215-218.

Singh Y, Joshi SC, Satyawali V, et al., (2014): "Acute aluminium phosphide poisoning, what is new?". The Egyptian journal of internal medicine, 26 (3): 99-103.

Stephenson JB (1967): "Zinc phosphide poisoning". Archives of Environmental Health, 15: 83-88.

Tripathi SK and Pandey SK, (2007): "The effect of aluminium phosphide on the human brain: a histological study". Med. Sci. Law, 47:141-146.

Vijayanath V, Anitha MR, Raju GM, et al., (2011): "Forensic view on aluminium phosphide poisoning". Journal of Indian Academy of Forensic Medicine, 33(4): 289-291.

Wahab A, Zaheer MS, Wahab S, et al., (2008): "Acute aluminium phosphide poisoning”. Hon Kong Journal of Emergency Medicine; 15: 152-155.

Wexler P, (2005): Encyclopedia of Toxicology, $2^{\text {nd }}$ Ed. vols. 1 and 2, Academic Press. 
Yardan T, Cevik Y, Donderici O, et al. (2009) : "Elevated serum S100B protein and neuronspecific enolase levels in carbon monoxide poisoning”. Am J Emerg Med, 27: 838-842.

Yardan T, Cevik Y, Donderici O, et al., (2009): "Elevated serum S100B protein and neuron- specific enolase levels in carbonmonoxide poisoning”. Am J Emerg Med, 27: 838-842.

Zimmer DB, Cornwall EH, Landar A, et al., (1995): “The

S100 protein family: history, function, and expression”. Brain Res Bull, 37: 417-429.

\section{الملخص العربي}

\section{الدورالمحتمل لبروتين S-100及 في تقييم تأثر الجهاز العصبي المركزي والتنبؤ بالوفيات في حالات التسمم الحاد بالفوسفيدات}

\section{مروة محمد شاهين و أروة أحمد أبو الفضل ا و أحمد نبيل محمد زكي؟}

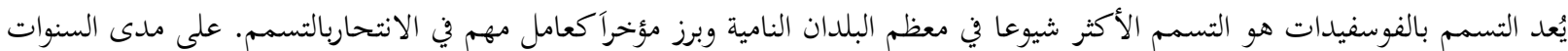

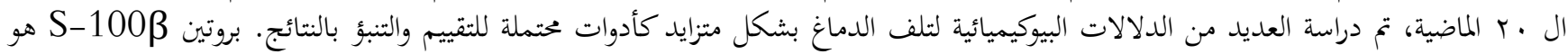

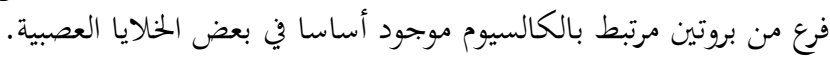

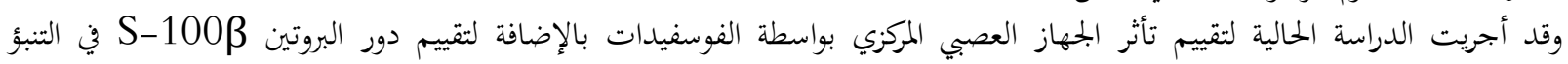
بالوفيات بعد التسمم الحاد بالفوسفيدات.

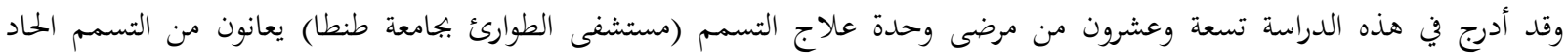

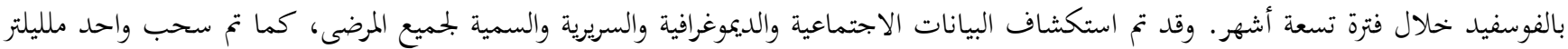

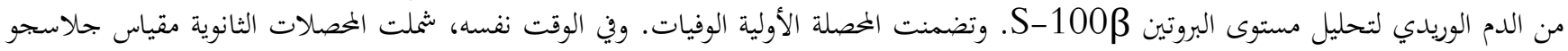

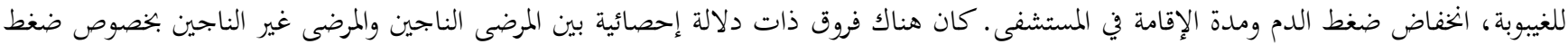

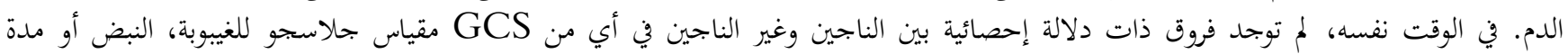

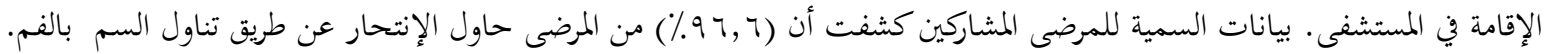

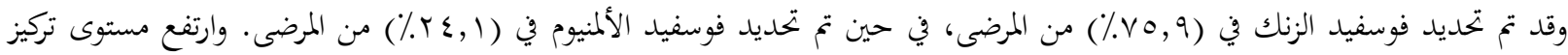

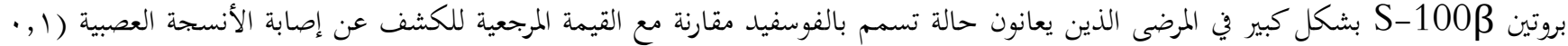

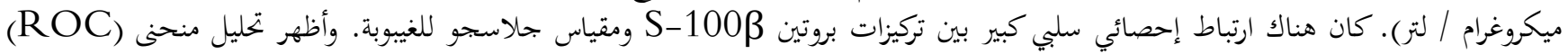

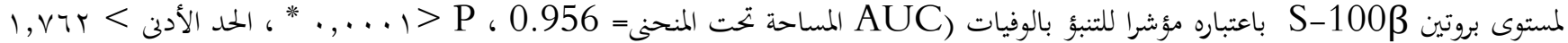

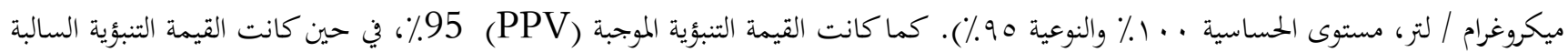
$\% 100$ (NPV)

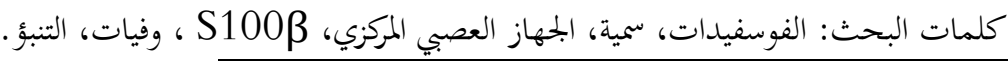

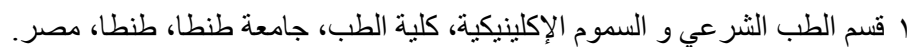
r قسم الباثولوجيا الاكلينيكية ، كلية الطب، جامعة طنطا، طنطا، مصر. 